\title{
Kontribusi Desain Komunikasi Visual dalam Anti-Hoax System saat Pandemi Covid-19 di Indonesia*
}

\author{
Marsudi $^{1}$, Muchammad Bayu Tejo Sampurno ${ }^{2}$, Condro Wiratmoko ${ }^{3}$, Fera \\ Ratyaningrum ${ }^{4}$ \\ 1,2,4Universitas Negeri Surabaya, ${ }^{3}$ SMA N 2 Surabaya \\ 10.15408/sjsbs.v7i10.15844
}

\begin{abstract}
:
This research wants to discuss the tendency of hoaxes to emerge during the Covid-19 pandemic in Indonesia, and as a solutive measure is to explore the contribution of Visual Communication Design as an anti-hoax system during the Covid-19 pandemic in Indonesia. This study uses qualitative methods combined with key points of the virtual ethnographic approach. The results showed (1) the dissemination of false information or hoaxes caused by the ease in forwarding information; (2) the convenience is ironically not followed by critical thinking power based on academics so that false information and hoaxes can easily spread in the community; (3) Visual Communication Design can be a solution by getting the potential designers to think critically and explore creative ideas in their work with research-based; (4) Visual communication designers are able to provide a sense of comfort to the public with works that also pay attention to their psychological psychological effects.

Keywords: Contribution; Design, anti-hoax system; Indonesian Covid-19 pandemic
\end{abstract}

\begin{abstract}
Abstrak:
Penelitian ini ingin membahas tentang kecenderungan maraknya hoax saat pandemi Covid19 di Indonesia, dan sebagai tindakan solutif adalah mengeksplorasi kontribusi Desain Komunikasi Visual sebagai anti-hoax system saat pandemi Covid-19 di Indonesia. Penelitian ini menggunakan metode kualitatif yang dipadukan dengan poin kunci pendekatan etnografi virtual. Hasil penelitian menunjukkan (1) penyebaran informasi palsu atau hoax disebabkan karena kemudahan dalam meneruskan informasi; (2) kemudahan tersebut ironisnya tidak diikuti dengan daya pemikiran kritis yang berlandaskan akademis sehingga informasi palsu dan hoax dapat dengan mudah menyebar di masyarakat; (3) Desain Komunikasi Visual dapat menjadi solusi dengan cara membiasakan calon desainernya untuk berpikiran kritis dan melakukan eksplorasi ide kreatif dalam karyanya dengan berbasis riset; (4) Desainer komunikasi visual mampu memberikan rasa nyaman kepada masyarakat dengan karya yang turut memerhatikan efeknya terhadap psikologis penontonnya.
\end{abstract}

Kata kunci: Kontribusi; Desain; Anti-Hoax System; Pandemi Covid-19, Indonesia

* Received: May 13, 2020, Revision: June 22, 2020, Published: October 14, 2020.

${ }^{1}$ Marsudi adalah Ketua Jurusan Desain, Fakultas Bahasa dan Seni, Universitas Negeri Surabaya. E-mail: marsudi@unesa.ac.id

${ }^{2}$ Muchammad Bayu Tejo Sampurno adalah dosen di Jurusan Seni Rupa, Fakultas Bahasa dan Seni, Universitas Negeri Surabaya. E-mail: m.bayutejo@gmail.com

${ }^{3}$ Condro Wiratmoko adalah guru Seni Budaya di SMA N 2 Surabaya, Jawa Timur. E-mail: condwier@gmail.com.

${ }^{4}$ Fera Ratyaningrum adalah Sekertaris Jurusan Seni Rupa, Fakultas Bahasa dan Seni, Universitas Negeri Surabaya. E-mail: feraratyaningrum@unesa.ac.id. 


\section{A. PENDAHULUAN}

Publik dunia sedang dilanda permasalahan terkait kesehatan. Setelah mengalami perjalanan yang panjang, akhirnya Coronavirus (Covid-19) sebagai evolusi dari Severe Acute Respiratory Syndrome (SARS) muncul sebagai penyakit menular. Covid19 disebabkan oleh coronavirus versi baru yang ditemukan pada akhir 2019 di Wuhan, China. ${ }^{5}$ Covid-19 memberikan gangguan dalam pernapasan baik tingkat ringan hingga sedang dan sembuh tanpa memerlukan perawatan khusus, ${ }^{6}$ namun memiliki penularan yang cepat. Lebih lanjut, prosentase penularannya lebih menyasar pada individu usia lanjut dan individu dengan riwayat masalah medis kronis seperti kardiovaskular, diabetes, penyakit pernapasan kronis, dan kanker. ${ }^{7}$ Individu dengan penyakit kronis tersebut apabila terjangkit Covid-19 maka akan mengembangkan virus tersebut menjadi penyakit yang lebih serius dan berakibat fatal. Hal tersebut yang membuat masyarakat musti waspada terhadap virus Covid-19 ini.

Secara perjalanannya, kasus pertama virus corona bermula pada periode 1960 yang awalnya dianggap sebagai influenza dengan sekitar 500 pasien diidentifikasi mengalami gagguan yang menyerupai flu. ${ }^{8}$ Setelahnya, corona dikategorikan sebagai virus yang tidak mematikan dan dianggap sederhana sampai periode tahun 2002. Pasca adanya Severe Acute Respiratory Syndrome (SARS-Cov) di China, para pakar mulai berfokus pada penyebab dan menemukan hasil apabila wabah ini diakibatkan oleh bentuk baru corona9 ${ }^{9}$ ditambah lagi dengan kabar bahwa ada bentuk baru dari virus tersebut pada 2012 yakni Middle East Respiratory Syndrome (MERS-Cov) di Timur Tengah $^{10}$. Dari kedua peristiwa itulah diketahui bahwa corona bukan virus yang stabil dan mampu bermutasi menjadi lebih ganas dan mengakibatkan kematian.

Virus corona terbaru, sampai akhir Mei 2020 mencapai 25.000 penderita ${ }^{11}$. Oleh karenanya, langkah pencegahan dan penanganan terus digalakkan untuk memutus atau setidaknya mencegah penyebaran lebih luas dari virus ini. Selain pola hidup bersih sebagai pencegahan secara fisik yang dapat dilakukan oleh masyarakat, perlu diperhatikan pula terkait kondisi psikis masyarakat salah satunya dalam menyikapi

5 World Health Organization, “Coronavirus," last modified 2020, accessed April 3, 2020, https://www.who.int/health-topics/coronavirus\#tab=tab_1.

6 "Covid-19 Coronaviruses Pandemic," accessed April 3, 2020, https://www.worldometers.info/coronavirus/; Wang Zhou, ed., Coronavirus Prevention Handbook (Wuhan: Hubei Science and Technology Press, 2020).

7 Kemkes, “Tentang Novel Coronavirus (NCOV)," last modified 2020, accessed April 3, 2020, https://www.kemkes.go.id/resources/download/info-terkini/COVID-19/TENTANG NOVEL CORONAVIRUS.pdf; “Covid-19 Coronaviruses Pandemic”; Zhou, Coronavirus Prevention Handbook; Scripps Research Institute, “COVID-19 Coronavirus Epidemic Has a Natural Origin,” Science Daily, last modified 2020, accessed April 3, 2020, https://www.sciencedaily.com/releases/2020/03/200317175442.htm.

${ }^{8}$ Dharmendra Kumar, Rishabha Malviya, and Pramod Kumar Sharma, "Corona Virus: A Review of COVID-19," Eurasian Journal of Medicine and Oncology 4, no. 2 (2020): 8-25.

${ }^{9}$ Ibid.

${ }^{10}$ Ibid.; Scripps Research Institute, “COVID-19 Coronavirus Epidemic Has a Natural Origin.”

11 “Covid-19 Indonesia,” accessed May 30, 2020, https://www.covid19.go.id/. 
pandemi ini dalam ranah media sosial dan penyebaran informasi secara siber ${ }^{12}$. Internet merupakan penyebar informasi yang cepat dan mampu melewati batasan secara fisik ${ }^{13}$. Artinya, internet mampu menyebarkan informasi sampai ke pelosok penjuru dunia, dan informasi tersebut dapat diakses oleh banyak pihak. Hal tersebut terkoneksi dengan paradigma revolusi industri 4.0 yang menghadirkan pengembangan robotic, artificial intelligence, internet of things, virtual reality, dan mahadata (big data) ${ }^{14}$. Revolusi industri 4.0 menghasilkan ketergagapan, disrupsi, sekaligus peluang.

Internet sebagai sebuah komponen besar komunikasi juga turut memiliki andil dalam mengubah perilaku risiko kesehatan ${ }^{15}$. Pengisi konten internet yang bervariasi antara lain mulai dari desainer, akademisi, dan para jurnalis berita, menyebabkan munculnya informasi yang bervariasi pula dari segi konten maupun visualisasinya ${ }^{16}$. Bidang Desain Komunikasi Visual merupakan salah satu yang perlu diperhatikan dalam kaitannya dengan penyebaran informasi dalam dunia siber karena memiliki kekuatan dalam aspek visual. Dari hasil penelitian, banyak ditunjukkan bahwasanya Desain Komunikasi Visual mampu menarik perhatian masyarakat karena pada dasarnya perhatian individu dalam penglihatan pertamanya terhadap suatu hal adalah 10 detik awal. ${ }^{17}$ Desain Komunikasi Visual mampu menjadi aset dan berperan penting, karena memiliki unsur visual dalam penyampaiannya. Tanpa perlu waktu yang lama, Desain Komunikasi Visual mampu mentrasfer informasi yang cenderung mudah diterima oleh

${ }^{12}$ Tzu-Bin Lin, Victor Chen, and Ching Sing Chai, eds., New Media and Learning in the 21st Century;
A Social-Cultural $\quad$ Perspektivererer, http://eric.ed.gov/ERICWebPortal/recordDetail?accno=EJ745810.

13 Alison Colman, "Net.Art and Net.Pedagogy: Introducing Internet Art to the Digital Art Curriculum," Studies in Art Education 46, no. Technology Issue (2018): 61-73; Stibe Ala, Alluhaidan; Samir, Chatterjee; Agnis, "Persuasive Technology 13th," in 13th International Conference of PERSUASIVE 2018, Waterloo, ON, Canada, April 18-19, 2018, ed. Jaap Ham et al. (Waterloo: Springer, 2018), http://dx.doi.org/10.1007/978-3-319-78978-1_25.

14 Yasraf Amir Piliang, "Seni, Desain, Dan Kebudayaan Dalam Spirit Revolusi Industri 4.0," in Prosiding Seminar Nasional Desain Dan Arsitektur (SENADA), vol. 2 (Bali: Sekolah Tinggi Desain Bali, 2019), 1-9; I Ketut Putu Suardana, "Resolution of Jurnalistic Ethics on Media Disruption Era," Media Bina Ilmiah 21, no. 1 (2020): 1-9; Lin, Chen, and Chai, New Media and Learning in the 21st Century; A Social-Cultural Perspektive; Scott Taylor, "Integrating Performance Studies into the Foreign Language Curriculum via Digital Media: New Adventures in Multiliteracies," French Review 87, no. 1 (2013): 113-124.

${ }^{15}$ Julia M. Alber et al., "Social Media Self-Efficacy of Health Education Specialists," Health Promotion Practice 17, no. 6 (2016): 915-921; Carl Hanson et al., “Use and Acceptance of Social Media among Health Educators," American Journal of Health Education 42, no. 4 (2011): 197-204; Elaine Bratic Arkin, “Opportunities for Improving the Nation's Health through Collaboration with the Mass Media," Public Health Reports 105, no. 3 (1990): 219-223.

16 Anne Morgan Spalter and Andries Van Dam, “Digital Visual Literacy,” Theory into Practice 47, no. 2 (2008): 93-101; Lin, Chen, and Chai, New Media and Learning in the 21st Century; A Social-Cultural Perspektive.

17 Fatos Adiloglu, "Visual Communication: Design Studio Education through Working the Process," Procedia - Social and Behavioral Sciences 28 (2011): 982-991, http://dx.doi.org/10.1016/j.sbspro.2011.11.182; Carlos Figueiredo, "Narrative and Visual Cinematic Strategies in Communication Design," Procedia Manufacturing 3, no. Ahfe (2015): 4358-4361, http://dx.doi.org/10.1016/j.promfg.2015.07.431; Cover Design et al., Visual Communication Design, n.d. 
masyarakat ketimbang membaca konten atau isi berita yang berupa tulisan atau wujud tekstual. ${ }^{18}$

Oleh karena itu, penelitian ini ingin mengeksplorasi peran Desain Komunikasi Visual sebagai anti-hoax saat pandemi Covid-19 di Indonesia. Hal tersebut juga didasari dari mencermati liberalisasi pasar global ataupun perdagangan bebas dalam lingkup internasional (WTO), lingkup regional (APEC), lingkup sub-regional (Masyarakat Ekonomi ASEAN), dan dengan kesepakatan GATT, AFTA telah diberlakukan, berdampak kesempatan kerjasama yang seluas-luasnya antar negara yang dapat menyebabkan internasional hoax jika tidak diperhatikan secara serius. Lebih lanjut, penelitian ini ingin mengeksplorasi tantangan bagi para desainer komunikasi visual untuk meningkatkan daya saing secara komunikasi visual sebagai sektor jasa yang mengandalkan integrasi antara intelektualitas dan kemampuan artistik ${ }^{19}$.

\section{B. METODE PENELITIAN}

Metode penelitian ini adalah deskriptif kualitatif dengan mengambil beberapa poin dalam pendekatan etnografi virtual. ${ }^{20}$ Etnografi virtual mengacu pada pendekatan penelitian etnografi yang dilakukan dalam pengaturan online. ${ }^{21}$ Poin-poin etnografi virtual yang diambil turut membantu peneliti dalam mempelajari kecenderungan komunal dan penyebaran informasi terkait Covid-19 di Indonesia. ${ }^{22}$ Pengumpulan data dilakukan secara kepustakaan dan studi dokumentasi. Selain itu data didukung dengan kuesioner yang disebarkan melalui google form selama bulan Mei 2020. Kriteria responden adalah berusia antara 13-40 tahun. Kriteria tersebut dipilih agar mendapatkan hasil yang variatif terkait kecenderungan penggunaan internet di Indonesia. Data yang terkumpul disajikan secara eksploratif untuk membahas tentang kontribusi Desain Komunikasi Visual terhadap berita hoax saat pandemi Covid-19 d Indonesia.

18 Gulcan Numanoglu and Safak Bayir, "Evaluation of Information and Communication Technology Textbooks According to Principles of Visual Design," Procedia - Social and Behavioral Sciences 1, no. 1 (2009): 2140-2144, http://dx.doi.org/10.1016/j.sbspro.2009.01.375; Adiloglu, “Visual Communication: Design Studio Education through Working the Process."

${ }^{19}$ Design et al., Visual Communication Design; Gunther Kress and Theo van Leeuwen, Reading Images: The Grammar of Visual Design (London: Routledge, 2012); Indro Moerdisuroso, "Social Semiotics and Visual Grammar: A Contemporary Approach to Visual Text Research," International Journal of Creative and Arts Studies 1, no. 1 (2014): 80091; Gordon Graham, Philosophy of the Art (London: Routledge, 1997).

${ }^{20}$ Norman K. Denzin and Yvonna S. Lincoln, eds., The SAGE Handbook of Qualitative Research, Fifth Edit. (Los Angeles: Sage Publications, 2018); Particia Leavy, Research Design: Quantitative, Qualitative, Mixed Methods, Arts-Based, and Community-Based Participatory Research Approaches (New York: The Guilford Press, 2017); Howard Lune and Bruce L. Berg, Qualitative Research Methods for the Social Sciences, Ninth edit. (Essex: Pearson, 2017).

${ }^{21}$ Tom Boellstorff et al., Ethnography and Virtual Worlds: A Handbook of Method (UK: Princeton University Press, 2012); Johannes Fabian, Ethnography as Commentary: Writing Form the Virtual Archive (Durham dan London: Duke University Press, 2008); Christine Hine, Virtual Ethnography (London: Sage Publications, 2001).

22 Boellstorff et al., Ethnography and Virtual Worlds: A Handbook of Method; Kathy A. Mills, Big Data for Qualitative Research, Routledge Focus (Oxon: Routledge, 2019). 


\section{ANALISIS DAN PEMBAHASAN}

\section{Posisioning Desain Komunikasi Visual saat ini}

Desain Komunikasi Visual (DKV), merupakan bidang profesi yang berkembang pesat sejak revolusi industri (abad ke-19). ${ }^{23}$ Pada periode tersebut informasi melalui media cetak semakin luas digunakan dalam perdagangan (poster dan kemasan), penerbitan (koran, buku dan majalah) dan informasi seni budaya. ${ }^{24}$ Perkembangan bidang ini pada abad ke-20 menemukan bentuknya yang baru terutama ketika peranan komunikasi yang diemban semakin beragam meliputi; informasi umum (information graphics, signage), pendidikan (materi pelajaran dan ilmu pengetahuan, pelajaran interaktif pendidikan khusus), persuasi (promosi) dan pemantapan identitas (logo, corporate identity, branding) ${ }^{25}$. Munculnya istilah Desain Komunikasi Visual sebenarnya juga merupakan akibat dari semakin meluasnya media yang dicakup dalam bidang komunikasi lewat bahasa rupa antara lain percetakan (grafika), film dan video, televisi, web design dan CD interaktif.

Perkembangan keilmuan dan keprofesian dalam bidang Desain Komunikasi Visual saat ini telah mengalami perkembangan yang sangat pesat yang ditandai oleh lahirnya kajian-kajian secara keilmuan dalam Desain Komunikasi Visual yang berkaitan dengan disiplin lingusitik (semiotic), sosiologi, antropologi, psikologi, kebudayaan, ekonomi (manajemen) hingga teknologi. ${ }^{26}$ Dampak terjadinya irisan antara disiplin keilmuan Desain Komunikasi Visual dengan keilmuan lainnya mampu melahirkan kajian-kajian ilmiah dengan tema-tema seperti wacana narasi visual, antropologi visual, budaya visual, branding, digital storytelling, digital illustration, digital animation, web design, hingga game design. Sebagai akibat adanya fenomena persentuhan disiplin keilmuan tersebut ke dalam bidang Desain Komunikasi Visual, maka secara bersamaan diikuti pula oleh munculnya profesi-profesi kebaruan dalam bidang Desain Komunikasi Visual, antara lain digital illustrator, digital animator, game designer, web designer, dan videographer. ${ }^{27}$

Semakin kompleksnya keilmuan Desain Komunikasi Visual, dan disertai tantangan masalah-masalah disintegrasi bangsa, maka para desainer komunikasi visual perlu menyiapkan dirinya secara mentalitas dan intelektualitas sebagai desainer yang memiliki kompetensi dan memiliki strategi untuk menghadapi perubahan dan

${ }^{23}$ Bryony Gomez-palacio and Armin Vit, Graphic Design Referenced: A Visual Guide to the Language, Applications, and History of Graphic Design (Massachusetts: Rockport Publishers, Inc., 2009).

${ }^{24}$ Ibid.

${ }^{25}$ Stephanie Rosenbaum and Joe Bugental, "Measuring the Success of Visual Communication in User Interfaces," Technical Communication 45, no. 4 (1998): 517-528.

${ }^{26}$ Guy Julier, "From Visual Culture to Design Culture," Design Issues 22, no. 1 (2017): 64-76; Frederic Darbellay and Zoe Moody, Creativity Design Thinking and Interdisiplinarity (Singapore: Springer Nature, 2017); Joe Moran, Interdisciplinarity (New York: Routledge, 2002); Colman, “Net.Art and Net.Pedagogy : Introducing Internet Art to the Digital Art Curriculum"; Perla Innocenti, "Preventing Digital Casualties : An Interdisciplinary Research for Preserving Digital Art," Leonardo 45, no. 5 (2019): 472-473.

27 Tim Kurikulum Program Studi Desain Komunikasi Visual, Dokumen Kurikulum 2013-2018 Program Studi Desain Komunikasi Visual Institut Teknologi Bandung (Bandung: Bidang Akademik dan Kemahasiswaan Institut Teknologi Bandung, 2013). 
tantangan. ${ }^{28}$ Desainer komunikasi visual juga perlu daya adaptasi tinggi dan cepat untuk menciptakan solusi baru atas berbagai masalah yang akan muncul di kemudian hari. ${ }^{29}$ Lebih lanjut, desainer komunikasi visual harus mempertimbangkan dan memerhatikan literasi digital merupakan kemampuan menggunakan teknologi dan informasi dari piranti digital secara efektif dan efisien dalam berbagai konteks seperti akademik, karir, dan kehidupan sehari-hari. ${ }^{30}$

Berpijak pada isu-su global dan bergulirnya revolusi industri 4.0 yang ditandai perkembangan teknologi yang sangat pesat tersebut, maka universitas pencetak desainer harus mempertimbangkan untuk menyelaraskan perkembangan global dengan mengedepankan karakter dan terus menumbuhkan sikap nasionalisme yang berbasis pada keragaman budaya nusantara. ${ }^{31}$ Munculnya isu-isu seperti hoax, radikalisme, dan intoleransi yang memberikan dampak pada disintegrasi bangsa merupakan tantangan bersama yang secara sadar harus dinternalisasikan dalam pendidikan, apalagi ketika pandemi Covid-19 yang telah dianggap sebagai bencana nasional di Indonesia ini berlangsung.

Studi terkait Desain Komunikasi Visual saat ini merupakan salah satu studi wajib yang diharapkan mampu berkontribusi dalam menjawab berbagai macam tantangan global, serta pemecahan masalah (problem solving) atas isu-isu yang berkaitan dengan penyebaran informasi agar masyarakat memiliki rasa tenang dalam menghadapi pandemi Covid-19 ini. Terlebih, internet secara signifikan telah memebrikan tempatnya untuk dieksplorasi oleh bidang keilmuan desain. ${ }^{22}$ Oleh karenanya, mengenali dampak internet terhadap masyarakat dan budaya sangat penting, di mana jelas bahwa internet dapat memengaruhi budaya melalui kebebasan dan fleksibilitasnya. ${ }^{33}$ Efeknya bahkan dapat dianggap sebagai budaya sendiri. ${ }^{34}$ Jika dipelajari hasilnya, kolaborasi internet dan budaya di Indonesia dapat membantu menjadikan internet lebih bermanfaat dengan berfokus pada keakuratan informasi dengan menyadari keterbatasannya dan memunculkan desain sebagai media penyeimbang dan peningkatan kualitasnya.

${ }^{28}$ Moerdisuroso, “Social Semiotics and Visual Grammar: A Contemporary Approach to Visual Text Research"; Brittany Torrez, Cheryl Wakslak, and Elinor Amit, “Dynamic Distance: Use of Visual and Verbal Means of Communication as Social Signals," Journal of Experimental Social Psychology 85, no. August 2018 (2019): 103849, https://doi.org/10.1016/j.jesp.2019.103849.

${ }^{29}$ Julie Grossman, Adaptation in Visual Culture, Adaptation in Visual Culture (New York: Palgrave Macmillan, 2017).

30 Spalter and Van Dam, "Digital Visual Literacy."

${ }^{31}$ Marsudi, "Revitalisasi Kurikulum Desain Komunikasi Visual Berbasis Digital” (Gorontalo: Tidak diterbitkan, 2019).

${ }^{32}$ Colman, "Net.Art and Net.Pedagogy : Introducing Internet Art to the Digital Art Curriculum."

${ }^{33}$ Lin, Chen, and Chai, New Media and Learning in the 21st Century; A Social-Cultural Perspektive.

${ }_{34}$ Muchammad Bayu Tejo Sampurno, Tri Cahyo Kusumandyoko, and Muh Ariffudin Islam, "Budaya Media Sosial, Edukasi Masyarakat, Dan Pandemi COVID-19," SALAM: Jurnal Sosial dan Budaya Syar-i 7, no. 5 (2020). 


\section{Hoax dan pandemi Covid-19}

Hoax bukanlah hal yang baru, tetapi namun dengan perkembangan teknologi digital, media sosial dan siklus berita siber semakin mempermudah dalam membuat penyebaran informasi hoax dengan lebih cepat dan lebih luas ${ }^{35}$. Mulai tahun 1990-an internet mulai menjadi penyedia utama berita dan informasi. ${ }^{36}$ Netscape memperkenalkan browser web pertama pada tahun 1994, dan Microsoft mengikutinya pada tahun 1995 dengan Explorer. Lalu Google muncul dengan memperkenalkan mesin pencari pada tahun 1998 dan dengan cepat mendominasi pencarian internet. Pengaruh internet kemudian berlipat ganda dengan maraknya media sosial. LinkedIn diperkenalkan pada 2002 diikuti oleh Myspace pada 2003. Platform ini segera dikalahkan oleh Facebook, yang diluncurkan pada 2004 dan dengan cepat naik untuk mendaftarkan sekitar 2,2 miliar pengguna. YouTube memulai debutnya pada tahun 2005 dan diakuisisi oleh Google pada tahun 2006, tahun yang sama ketika Twitter melakukan debutnya. Instagram muncul di dunia pada 2010, dan Snapchat online pada 2011. Platform media sosial semakin berkembang dengan masif sampai saat ini.

Media sosial tidak hanya muncul sebagai ajang silaturahmi secara maya, namun juga sebagai salah satu penyebar informasi, atau sebagai penyebar berita melalui internet. Kekuatan platform berita internet alternatif ini diperkuat oleh kecenderungan istilah troll dan bot internet. Troll adalah oknum yang menggunakan media sosial untuk memulai pertengkaran, membuat marah orang, dan menabur kebingungan di antara para pengguna dengan menyebarkan informasi online yang palsu. ${ }^{37}$ Banyak troll sebenarnya adalah bot yang merupakan akun otomatis yang berpura-pura menjadi manusia di mana mampu diprogram untuk menyebarkan cerita palsu dan menyesatkan dengan cepat melalui jejaring sosial online. ${ }^{38}$

Di saat pandemi Covid-19 ini terjadi, masyarakat banyak dibingungkan oleh informasi palsu. Misalnya jaringan konspirasi online menyatakan bahwa Covid-19 adalah aksi terorisme biologis untuk menyerang perdagangan Cina; ${ }^{39}$ ada pula yang mengatakan bahwa virus itu adalah tipuan yang dibuat untuk menimbulkan ketakutan global dan karenanya akan menjadi keuntungan bagi situs riset di luar negeri, dan masih banyak lagi. Hal tersebut dipengaruhi dan sesuai dengan tujuan hoax untuk konspirasi. Mudahnya masyarakat untuk terbawa arus hoax dikarenakan minimnya literasi. Masyarakat tidak cenderung memiliki pola membaca kritis terhadap suatu hal dan mencoba melakukan konfirmasi secara empiris dan akademis terhadap fenomena tersebut.

35 Gabriele Cosentino, Social Media And The Post-Truth World Order: The Global Dynamics Of Disinformation (London: Palgrave Pivot, 2020); Ralph Keyes, The Post-Truth Era: Dishonesty and Deception in Contemporary Life (New York: St. Martin's Press, 2004).

36 Spalter and Van Dam, "Digital Visual Literacy."

${ }^{37}$ Cosentino, Social Media And The Post-Truth World Order: The Global Dynamics Of Disinformation; Keyes, The Post-Truth Era: Dishonesty and Deception in Contemporary Life.

${ }^{38}$ Cosentino, Social Media And The Post-Truth World Order: The Global Dynamics Of Disinformation.

39 Scripps Research Institute, "COVID-19 Coronavirus Epidemic Has a Natural Origin"; Kumar, Malviya, and Sharma, "Corona Virus: A Review of COVID-19." 


\section{Dunia internet dan desain di Indonesia: Solusi riset seni dalam anti-hoax system}

Dunia siber atau internet di Indonesia memiliki konsekuensi di mana membutuhkan waktu bertahun-tahun kepada manfaat positif untuk diterapkan sepenuhnya. Internet secara signifikan mempengaruhi pola hidup masyarakat Indonesia dengan kecepatan akses dan perkembangan teknologinya. ${ }^{40}$ Misalnya, individu telah mengubah topik dan cara komunikasi, frekuensi, dan kebiasaan mereka sebagai akibat dari ketersediaan dan aksesibilitas alat komunikasi online. ${ }^{41}$ Perkembangan teknologi informasi komunikasi dan efek globalisasi yang luas mengubah cara suatu masyarakat memandang sebuah informasi yang dirasa dibutuhkan atau tidak samasekali dalam hidupnya. ${ }^{42}$ Konsep tersebut menyebabkan jurnalisme kehilangan makna konvensionalnya. Hal ini juga bisa dipandang sebagai kelemahannya di mana penyebaran hoax mudah berlangsung sebagai paket dari arus teknologi yang berkembang masif.

Terdapat penelitian yang mengatakan bahwa internet dapat merusak budaya terkait sifat keterbukaan melalui media sosial yang memungkinkan setiap informasi untuk dijangkau oleh siapa saja dan di mana saja, ${ }^{43}$ baik anak-anak atau orang dewasa. Siapapun penikmat internet dapat secara instan menyalin informasi apa saja yang masuk meskipun tidak relevan dengan realita dalam lingkungan yang mereka temukan. Di sisi lain, internet membawa informasi lebih dekat kepada lebih banyak individu, membuatnya lebih mudah dan cepat diakses; yang berpotensi memupuk munculnya bentuk-bentuk ekspresi baru dalam penyebaran informasi dan pengetahuan, ${ }^{44}$ termasuk kaitannya dengan pandemi Covid-19.

Oleh karenanya, dibutuhkan studi yang mendalam terhadap Desain Komunikasi Visual sebagai salah satu aset unggulan dalam bidang seni. Di dalam mata kuliah di universitas misalnya, desain muncul dalam berbagai capaian pembelajaran yang mampu mengeksplorasi proses dan hasil belajar mahasiswa baik dalam bentuk apresiasi dan kajian seni desain maupun produk seni seni desain dengan berlandaskan riset. ${ }^{45} \mathrm{Hal}$

\footnotetext{
${ }^{40}$ James Reveley, “The Exploitative Web: Misuses of Marx in Critical Social Media Studies," Science and Society 77, no. 4 (2013): 512-535.

41 Sampurno, Kusumandyoko, and Islam, "Budaya Media Sosial, Edukasi Masyarakat, Dan Pandemi COVID-19."

42 Scott Hamilton, Benjamin Martill, and Katharine Millar, "Power, the State, and the Social Media Network," St Antony's International Review 8, no. 2 (2013): 2-11.

${ }^{43}$ Reveley, "The Exploitative Web: Misuses of Marx in Critical Social Media Studies"; C. Sample et al., "A Cultural Exploration of Social Media Manipulators," Journal of Information Warfare 17, no. 4 (2018): $56-71$.

${ }^{44}$ Rebekah A Richert et al., “Media as Social Partners: The Social Nature of Young Children's Learning From Screen Media," Child Development 82, no. 1 (2011): 82-95; Jacquelyn S Kibbey, “Media Literacy and Social Justice in a Visual World," Counterpoints 403, no. Engaging Students in Glocal Issues through the Arts (2011): 50-61, http://www.jstor.org/stable/42981595.

${ }^{45}$ Daniel H. Bowen, Jay P. Greene, and Brian Kisida, “Learning to Think Critically: A Visual Art Experiment," Educational Researcher 43, no. 1 (2014): 37-44.
} 
tersebut bertujuan untuk semakin meningkatkan kemampuan berkesenian berbasis riset yang mampu mereduksi kecenderungan hoax di masa yang akan dating. ${ }^{46}$

Berdasarkan hasil metode pengambilan suara di Indonesia yang bekerja sama dengan Asosiasi Penyelenggara Jasa Internet Indonesia (APJII), jumlah pengguna internet di Indonesia pada tahun 2019 tumbuh 10,12\% persen. ${ }^{47}$ Selain itu, sebanyak $64,8 \%$ sudah terhubung ke internet dengan range usia terbanyak 15 sampai 19 tahun. Berdasarkan informasi tersebut maka tantangan utamanya adalah bagaimana membekali para desainer untuk dapat memproses berbagai informasi, memahami pesan, kesadaran dan berpikir kritis terhadap berbagai dampak positif dan negatif serta kemampuan berkomunikasi efektif dalam berbagai bentuk. Oleh karenanya perlu kemampuan literasi digital dalam menyikapi isu-isu global yang terjadi saat ini, terutama terkait Covid-19.

Gambar 1. Prosentase penggunaan media penyebar dan penerima informasi ${ }^{48}$

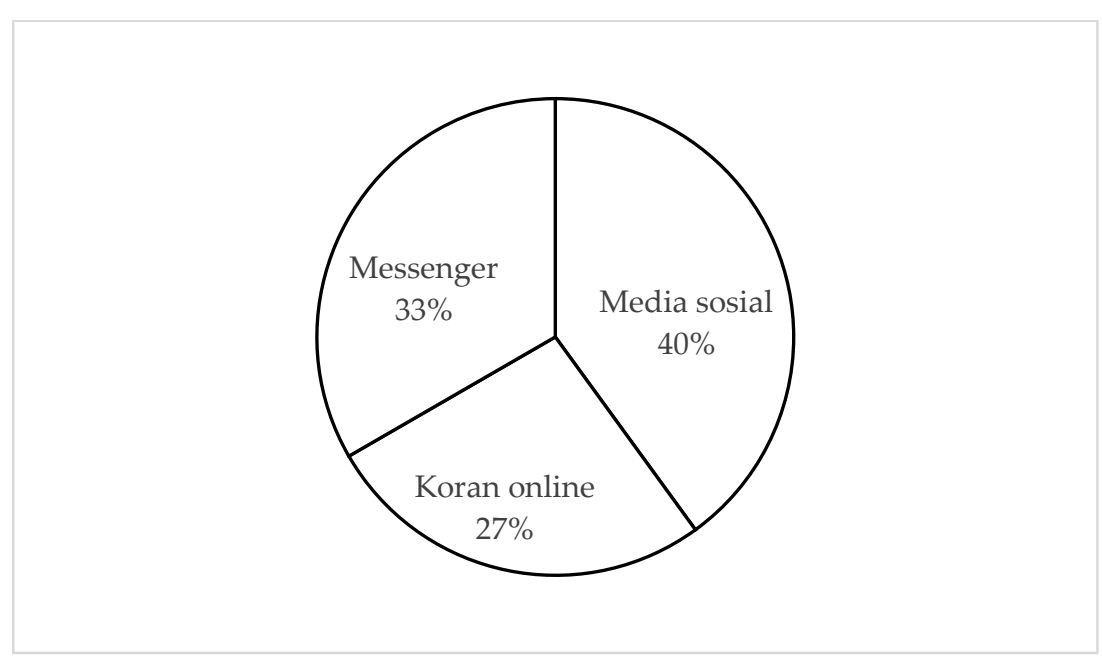

Hal tersebut sesuai dengan mayoritas masyarakat Indonesia yang lebih mengedepankan media sosial sebagai media mendapatkan dan menyebarkan informasi. Media sosial dapat dikatakan mampu 'mengalahkan' penggunaan koran online sebagai media masyarakat dalam mendapatkan informasi terkait Covid-19. Pengunaan messenger seperti WhatsApp, Line, Facebook Messenger, dan platform lainnya juga perlu dicermati. Karena, menurut situs Resmi Kominfo yang bisa diakses melalui kominfo.go.id, penyebaran hoax juga terdapat pada messenger, karena pengguna dapat dengan mudahnya meneruskan isi pesan dengan fitur 'forward'.

${ }^{46}$ Xichen Zhang and Ali A. Ghorbani, "An Overview of Online Fake News: Characterization, Detection, and Discussion," Information Processing and Management 57, no. 2 (2020): 102025, https://doi.org/10.1016/j.ipm.2019.03.004; Numanoglu and Bayir, "Evaluation of Information and Communication Technology Textbooks According to Principles of Visual Design."

47 Yudha Pratomo, “APJII: Jumlah Pengguna Internet Di Indonesia Tembus 171 Juta Jiwa," last modified 2019, accessed August 16, 2019, https://tekno.kompas.com/read/2019/05/16/03260037/apjii-jumlahpengguna-internet-di-indonesia-tembus-171-juta-jiwa.

${ }^{48}$ Survey dilakukan terhadap 90 responden melalui google form. Survey dilakukan pada bulan Mei 2020. 
Gambar 2. Distribusi penerimaan akses berita terkait Covid-1949

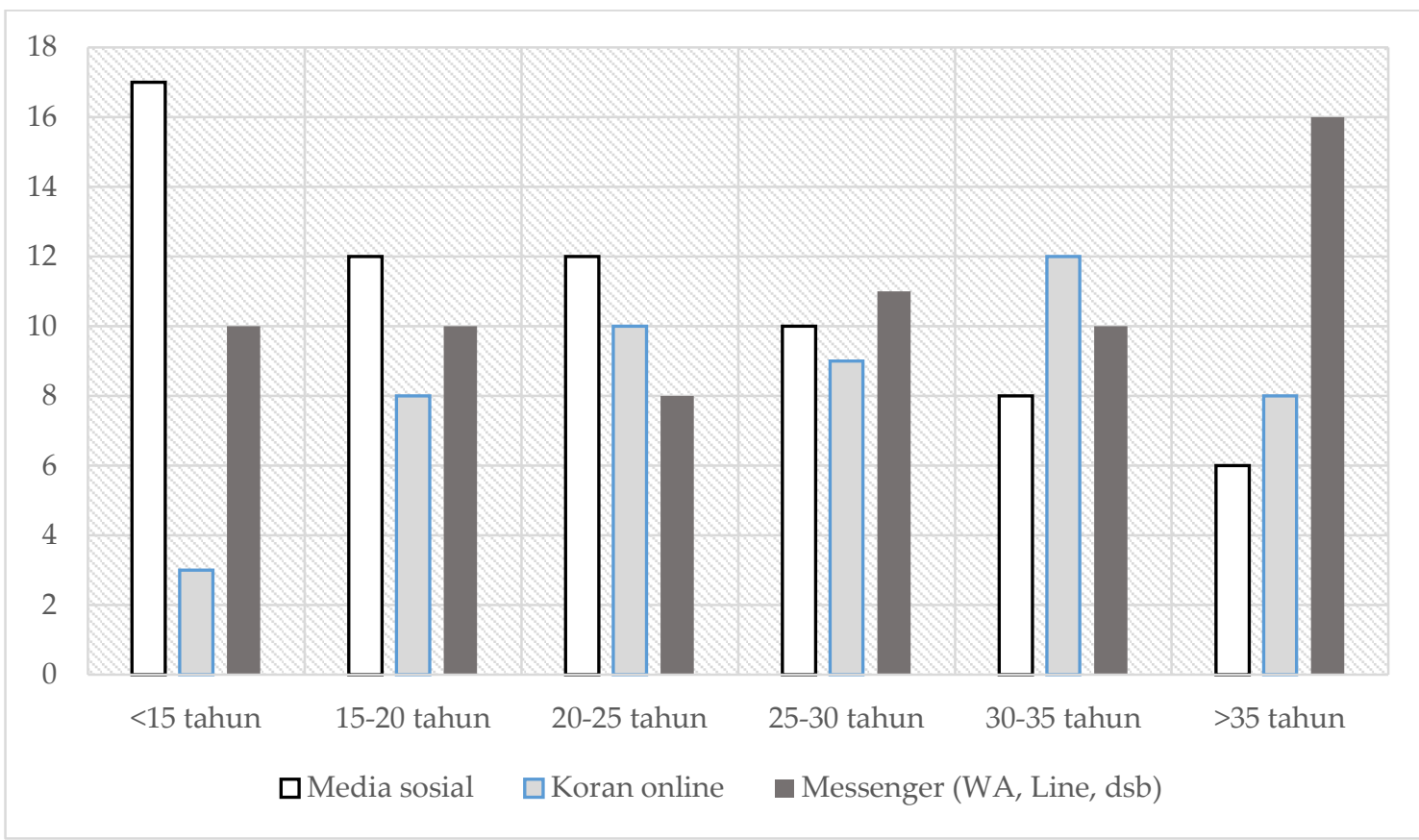

Pengguna media informasi online di Indonesia bervariasi. Menurut survey yang dilakukan terhadap masing-masing 30 responden, dapat ditunjukkan bahwa mereka memiliki kecenderungan platformnya masing-masing. Dalam usia remaja dan dewasa awal, kecenderungan terletak pada media sosial. Sedangkan usia produktif berada pada koran online dan messenger. Ketiga platform tersebut sebenarnya emrupakan sasaran empuk untuk menyebarkan hoax, karena mereka memiliki fitur yang memudahkan seseorang untuk meneruskan informasi yang diperoleh. Oleh karenanya, bidang Desain Komunikasi Visual diharapkan mampu menekan dengan pembiasaan yang telah disebutkan sebelumnya, yaitu art-based research dan led-research ketika membuat karya yang berkaitan dengan informasi publik. Budaya riset tersebut akan menanamkan pembiasaan akademik kepada para desainer sehingga semakin memahami kode etik dalam penyebaran informasi kepada public. ${ }^{50}$

${ }^{49}$ Survey dilakukan terhadap 90 responden melalui google form. Survey dilakukan pada bulan Mei

${ }^{50}$ Adiloglu, "Visual Communication: Design Studio Education through Working the Process.” 
Gambar 3. Survey terkait kepercayaan masyarakat terhadap desain komunikasi visual sebagai anti-hoax system ${ }^{51}$

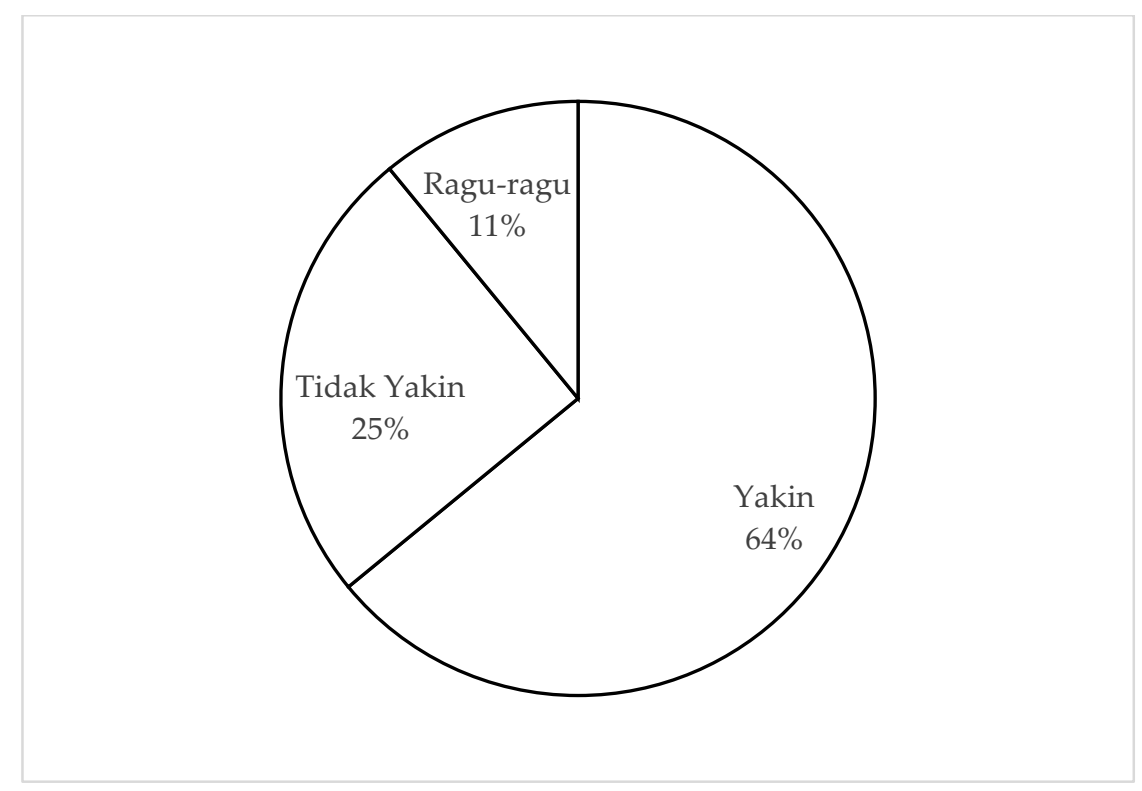

Desain Komunikasi Visual mendapatkan kepercayaan publik terkait fungsinya sebagai anti-hoax system. Kampanye yang dilakukan melalui Desain Komunikasi Visual antara lain dengan cara membuat karya desain bersifat layanan masyarakat yang mampu memberikan informasi dan edukasi kepada masyarakat dalam menghadapi pandemi Covid-19 ini ${ }^{52}$. Edukasi yang dilakukan oleh para desainer komunikasi visual, tentunya memiliki nilai estetik. ${ }^{53} \mathrm{Hal}$ tersebut dikarenakan kompetensi yang dimilikinya dan sense of art yang tinggi. ${ }^{54}$ Selain itu, desainer komunikasi visual secara simbolis mampu memasukkan unsur-unsur yang menenangkan melalui sistem tandanya, baik simbolisasi maupun pewarnaan.

\section{KESIMPULAN}

Penyebaran hoax di era disrupsi saat ini memang sulit untuk dicegah. Namun, berlandaskan pada sudut pandang akademik dalam kebiasaan riset, maa penyebaran

${ }^{51}$ Survey dilakukan terhadap 90 responden melalui google form. Survey dilakukan pada bulan Mei 2020.

${ }^{52}$ Margaret Slota et al., “Visual Intelligence Education as an Innovative Interdisciplinary Approach for Advancing Communication and Collaboration Skills in Nursing Practice," Journal of Professional Nursing 34, no. 5 (2018): 357-363, http://dx.doi.org/10.1016/j.profnurs.2017.12.007.

53 Zeynep Altinay and Nekesha Williams, "Visuals as a Method of Coastal Environmental Communication," Ocean and Coastal Management 178, no. April (2019): 104809, https://doi.org/10.1016/j.ocecoaman.2019.05.011; Marcel Danesi, Pesan Tanda Dan Makna (Yogyakarta: Jalasutra, 2010); Torrez, Wakslak, and Amit, "Dynamic Distance: Use of Visual and Verbal Means of Communication as Social Signals"; Allison Lazard and Michael Mackert, "User Evaluations of Design Complexity: The Impact of Visual Perceptions for Effective Online Health Communication," International Journal of Medical Informatics 83, no. 10 (2014): 726-735, http://dx.doi.org/10.1016/j.ijmedinf.2014.06.010.

54 Peter Goldie and Elisabeth Scellekens, Philosophy and Conceptual Art (New York: Oxford University Press, 2007); John Dewey, Art as Experience (New York: Perigee Books, 1980). 
hoax dapat diminimalisir. Hal ini memerlukan bantuan yang sungguh-sungguh dari akademisi dan universitas tempat para calon desainer menuntut ilmunya. Jika kultur riset digalakkan dalam proses berkarya para desainer, maka nantinya akan tercipta para desainer yang bertanggung jawab dan selalu melakukan proses berkarya dengan pendekatan saintifik. Oleh karenanya maka harus dipersiapkan rancangan kurikulum yang mampu menjawab perubahan dengan segala dampak yang ditimbulkan. Perkembangan teknologi digital selalu membawa dampak positif sebagai solusi dari permasalahan yang dihadapi oleh masyarakat.

\section{Referensi}

Adiloglu, Fatos. "Visual Communication: Design Studio Education through Working the Process." Procedia - Social and Behavioral Sciences 28 (2011): 982-991. http://dx.doi.org/10.1016/j.sbspro.2011.11.182.

Ala, Alluhaidan; Samir, Chatterjee; Agnis, Stibe. "Persuasive Technology 13th." In 13th International Conference of PERSUASIVE 2018, Waterloo, ON, Canada, April 1819, 2018, edited by Jaap Ham, Evangelos Karapanos, Plinio P. Morita, and Catherine M. Burns. Waterloo: Springer, 2018. http://dx.doi.org/10.1007/978-3319-78978-1_25.

Alber, Julia M., Samantha Paige, Michael Stellefson, and Jay M. Bernhardt. "Social Media Self-Efficacy of Health Education Specialists." Health Promotion Practice 17, no. 6 (2016): 915-921.

Altinay, Zeynep, and Nekesha Williams. "Visuals as a Method of Coastal Environmental Communication." Ocean and Coastal Management 178, no. April (2019): 104809. https://doi.org/10.1016/j.ocecoaman.2019.05.011.

Arkin, Elaine Bratic. “Opportunities for Improving the Nation's Health through Collaboration with the Mass Media." Public Health Reports 105, no. 3 (1990): 219-223.

Boellstorff, Tom, Bonnie Nardi, Celia Pearce, and T L Taylor. Ethnography and Virtual Worlds: A Handbook of Method. UK: Princeton University Press, 2012.

Bowen, Daniel H., Jay P. Greene, and Brian Kisida. "Learning to Think Critically: A Visual Art Experiment." Educational Researcher 43, no. 1 (2014): 37-44.

Colman, Alison. "Net.Art and Net.Pedagogy : Introducing Internet Art to the Digital Art Curriculum." Studies in Art Education 46, no. Technology Issue (2018): 61-73.

Cosentino, Gabriele. Social Media And The Post-Truth World Order: The Global Dynamics Of Disinformation. London: Palgrave Pivot, 2020.

Danesi, Marcel. Pesan Tanda Dan Makna. Yogyakarta: Jalasutra, 2010.

Darbellay, Frederic, and Zoe Moody. Creativity Design Thinking and Interdisiplinarity. Singapore: Springer Nature, 2017.

Denzin, Norman K., and Yvonna S. Lincoln, eds. The SAGE Handbook of Qualitative 
Research. Fifth Edit. Los Angeles: Sage Publications, 2018.

Design, Cover, B Y Marc, Foreword By, Marc Atlan, Design Media, and Publishing Limited. Visual Communication Design, n.d.

Dewey, John. Art as Experience. New York: Perigee Books, 1980.

Fabian, Johannes. Ethnography as Commentary: Writing Form the Virtual Archive. Durham dan London: Duke University Press, 2008.

Figueiredo, Carlos. "Narrative and Visual Cinematic Strategies in Communication Design." Procedia Manufacturing 3, no. Ahfe (2015): 4358-4361. http://dx.doi.org/10.1016/j.promfg.2015.07.431.

Goldie, Peter, and Elisabeth Scellekens. Philosophy and Conceptual Art. New York: Oxford University Press, 2007.

Gomez-palacio, Bryony, and Armin Vit. Graphic Design Referenced: A Visual Guide to the Language, Applications, and History of Graphic Design. Massachusetts: Rockport Publishers, Inc., 2009.

Graham, Gordon. Philosophy of the Art. London: Routledge, 1997.

Grossman, Julie. Adaptation in Visual Culture. Adaptation in Visual Culture. New York: Palgrave Macmillan, 2017.

Hamilton, Scott, Benjamin Martill, and Katharine Millar. "Power, the State, and the Social Media Network." St Antony's International Review 8, no. 2 (2013): 2-11.

Hanson, Carl, Joshua West, Brad Neiger, Rosemary Thackeray, Michael Barnes, and Emily Mcintyre. "Use and Acceptance of Social Media among Health Educators." American Journal of Health Education 42, no. 4 (2011): 197-204.

Hine, Christine. Virtual Ethnography. London: Sage Publications, 2001.

Innocenti, Perla. "Preventing Digital Casualties: An Interdisciplinary Research for Preserving Digital Art." Leonardo 45, no. 5 (2019): 472-473.

Julier, Guy. “From Visual Culture to Design Culture.” Design Issues 22, no. 1 (2017): 6476.

Kemkes. "Tentang Novel Coronavirus (NCOV)." Last modified 2020. Accessed April 3, 2020. https://www.kemkes.go.id/resources/download/info-terkini/COVID19/TENTANG NOVEL CORONAVIRUS.pdf.

Keyes, Ralph. The Post-Truth Era: Dishonesty and Deception in Contemporary Life. New York: St. Martin's Press, 2004.

Kibbey, Jacquelyn S. "Media Literacy and Social Justice in a Visual World." Counterpoints 403, no. Engaging Students in Glocal Issues through the Arts (2011): 50-61. http://www.jstor.org/stable/42981595.

Kress, Gunther, and Theo van Leeuwen. Reading Images: The Grammar of Visual Design. London: Routledge, 2012. 
Kumar, Dharmendra, Rishabha Malviya, and Pramod Kumar Sharma. "Corona Virus: A Review of COVID-19." Eurasian Journal of Medicine and Oncology 4, no. 2 (2020): 8-25.

Lazard, Allison, and Michael Mackert. "User Evaluations of Design Complexity: The Impact of Visual Perceptions for Effective Online Health Communication." International Journal of Medical Informatics 83, no. 10 (2014): 726-735. http://dx.doi.org/10.1016/j.ijmedinf.2014.06.010.

Leavy, Particia. Research Design: Quantitative, Qualitative, Mixed Methods, Arts-Based, and Community-Based Participatory Research Approaches. New York: The Guilford

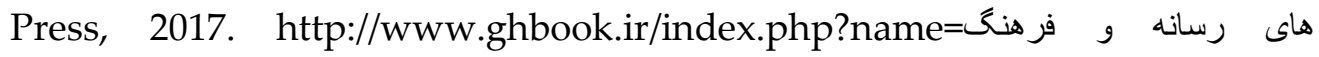
نوين ونoption=com_dbook\&task=readonline\&book_id=13650\&page=73\&chkha shk=ED9C9491B4\&Itemid=218\&lang=fa\&tmpl=component.

Lin, Tzu-Bin, Victor Chen, and Ching Sing Chai, eds. New Media and Learning in the 21st Century; A Social-Cultural Perspektive. Singapore: Springer, 2015. http://eric.ed.gov/ERICWebPortal/recordDetail?accno=EJ745810.

Lune, Howard, and Bruce L. Berg. Qualitative Research Methods for the Social Sciences. Ninth edit. Essex: Pearson, 2017.

Marsudi. "Revitalisasi Kurikulum Desain Komunikasi Visual Berbasis Digital." Gorontalo: Tidak diterbitkan, 2019.

Mills, Kathy A. Big Data for Qualitative Research. Routledge Focus. Oxon: Routledge, 2019.

Moerdisuroso, Indro. "Social Semiotics and Visual Grammar: A Contemporary Approach to Visual Text Research." International Journal of Creative and Arts Studies 1, no. 1 (2014): 80091.

Moran, Joe. Interdisciplinarity. New York: Routledge, 2002.

Numanoglu, Gulcan, and Safak Bayir. "Evaluation of Information and Communication Technology Textbooks According to Principles of Visual Design." Procedia Social and Behavioral Sciences 1, no. 1 (2009): 2140-2144. http://dx.doi.org/10.1016/j.sbspro.2009.01.375.

Piliang, Yasraf Amir. "Seni, Desain, Dan Kebudayaan Dalam Spirit Revolusi Industri 4.0." In Prosiding Seminar Nasional Desain Dan Arsitektur (SENADA), 2:1-9. Bali: Sekolah Tinggi Desain Bali, 2019.

Pratomo, Yudha. “APJII: Jumlah Pengguna Internet Di Indonesia Tembus 171 Juta Jiwa." Last modified 2019. Accessed August 16, 2019. https://tekno.kompas.com/read/2019/05/16/03260037/apjii-jumlah-penggunainternet-di-indonesia-tembus-171-juta-jiwa.

Reveley, James. "The Exploitative Web: Misuses of Marx in Critical Social Media Studies." Science and Society 77, no. 4 (2013): 512-535.

Richert, Rebekah A, Michael B Robb, Erin I Smith, Source Child Development, Raising Healthy, Children January, Rebekah A Richert, Michael B Robb, and Erin I Smith. “Media as Social Partners: The Social Nature of Young Children's 
Learning From Screen Media." Child Development 82, no. 1 (2011): 82-95.

Rosenbaum, Stephanie, and Joe Bugental. "Measuring the Success of Visual Communication in User Interfaces." Technical Communication 45, no. 4 (1998): $517-528$.

Sample, C., J. McAlaney, JZ Bakdash, and H Thackray. "A Cultural Exploration of Social Media Manipulators." Journal of Information Warfare 17, no. 4 (2018): 56-71.

Sampurno, Muchammad Bayu Tejo, Tri Cahyo Kusumandyoko, and Muh Ariffudin Islam. "Budaya Media Sosial, Edukasi Masyarakat, Dan Pandemi COVID-19." SALAM: Jurnal Sosial dan Budaya Syar-i 7, no. 5 (2020).

Scripps Research Institute. "COVID-19 Coronavirus Epidemic Has a Natural Origin." Science Daily. Last modified 2020. Accessed April 3, 2020. https://www.sciencedaily.com/releases/2020/03/200317175442.htm.

Slota, Margaret, Maureen McLaughlin, Lorena Bradford, Julia F. Langley, and Sarah Vittone. "Visual Intelligence Education as an Innovative Interdisciplinary Approach for Advancing Communication and Collaboration Skills in Nursing Practice." Journal of Professional Nursing 34, no. 5 (2018): 357-363. http://dx.doi.org/10.1016/j.profnurs.2017.12.007.

Spalter, Anne Morgan, and Andries Van Dam. "Digital Visual Literacy." Theory into Practice 47, no. 2 (2008): 93-101.

Suardana, I Ketut Putu. "Resolution of Jurnalistic Ethics on Media Disruption Era." Media Bina Ilmiah 21, no. 1 (2020): 1-9.

Taylor, Scott. "Integrating Performance Studies into the Foreign Language Curriculum via Digital Media: New Adventures in Multiliteracies." French Review 87, no. 1 (2013): 113-124.

Tim Kurikulum Program Studi Desain Komunikasi Visual. Dokumen Kurikulum 20132018 Program Studi Desain Komunikasi Visual Institut Teknologi Bandung. Bandung: Bidang Akademik dan Kemahasiswaan Institut Teknologi Bandung, 2013.

Torrez, Brittany, Cheryl Wakslak, and Elinor Amit. "Dynamic Distance: Use of Visual and Verbal Means of Communication as Social Signals." Journal of Experimental Social Psychology 85, no. August $2018 \quad$ (2019): 103849. https://doi.org/10.1016/j.jesp.2019.103849.

World Health Organization. “Coronavirus.” Last modified 2020. Accessed April 3, 2020. https://www.who.int/health-topics/coronavirus\#tab=tab_1.

Zhang, Xichen, and Ali A. Ghorbani. "An Overview of Online Fake News: Characterization, Detection, and Discussion." Information Processing and Management 57, no. 2 (2020): 102025. https://doi.org/10.1016/j.ipm.2019.03.004.

Zhou, Wang, ed. Coronavirus Prevention Handbook. Wuhan: Hubei Science and Technology Press, 2020. 
Marsudi, Muchammad Bayu Tejo Sampurno, Condro Wiratmoko, Fera Ratyaningrum

“Covid-19 Coronaviruses Pandemic." Accessed April 3, 2020. https://www.worldometers.info/coronavirus/.

“Covid-19 Indonesia." Accessed April 3, 2020. https://www.covid19.go.id/. 